TAPROBANICA, ISSN 1800-427X. October, 2010. Vol. 02, No. 02: pp. 65-71.

(C) Taprobanica Nature Conservation Society, 146, Kendalanda, Homagama, Sri Lanka.

\title{
EDITORIAL
}

\section{Asian Agamid lizards (Agamidae, Acrodonta, Sauria, Reptilia): Phylogenetic and taxonomic diversity}

The Southeast Asian-Indonesian and Australian-New Guinean tectonic plates have both been hypothesized to be centers of origin of agamid lizards (Moody, 1980). The Asian continent housed a number of hotspots of plant and animal diversity and endemism, important for the conservation of biodiversity on a global scale. There are many threatened areas in tropical Asia in terms of destruction of tropical rain forest as an environment with a unique biota and herpetofauna in particular. New intensive studies of the Asian fauna as well as new opportunities offered by molecular methods make it clear that taxonomic diversity is underestimated, especially in South and Southeast Asia. The aim of this paper is to show the taxonomic diversity of different evolutionary lineages and the distribution of agamids by sub region in Asia.

We compare several Asian territories well studied in diversity of agamids: China (Ananjeva \& Wang, 2008; Zhao \& Adler, 1993; Zhao et al., 1999); North Eurasia, i.e. former Soviet Union plus Mongolia (Ananjeva et al., 2006); Iran (Anderson, 1999); South Asia (Das, 1996; Das \& de Silva, 2005) and different regions of South-East Asia: Vietnam (Ananjeva et al., 2007); Thailand (Taylor, 1963 with additions); Myanmar (Zug et al., 2003); and the Sunda Archipelago (Manthey \& Grossmann, 1997).

The study of mitochondrial DNA (Ananjeva, 2004; Macey et al., 2000) has allowed the construction of a phylogenetic tree of acrodontan squamates and their main evolutionary lineages, which are associated with the fragmentation of Gondwana into separate tectonic plates. Such interpretations are based on the integration of morphological (Moody, 1980) and molecular data (Macey et al., 2000). Six groups of agamids correspond to 6 subfamilies: (1) Uromastycinae Theobald, 1868 with the genera Uromastyx and Saara; (2) Leiolepidinae Fitzinger, 1843 with the genus Leiolepis; (3) Amphibolurinae Wagler, 1830 with all Australian and New Guinean species; (4) Hydrosaurinae Kaup, 1828 with the genus Hydrosaurus; (5) South- and Southeast Asian Draconinae Fitzinger, 1826 with numerous Indian and Southeastern genera (mostly arboreal or semi-arboreal) and (6) Afro-West-Asian Agaminae Spix, 1825.

The Asian agamid fauna has a complicated origin. For example the highest phylogenetic variety in Asia with taxa belonging to 4 subfamilies Leiolepidinae, Amphibolurinae, Agaminae and Draconinae has been recorded in China (Ananjeva \& Wang, 2008); the fauna of agamid in South Asia is represented by 3 subfamilies: Agaminae, Draconinae and Uromastycinae (Das, 1996) as is that of Southeast Asia: Leiolepidinae, Amphibolurinae and Draconinae (Ananjeva et al., 2007) and Iran: Agaminae, Draconinae, Uromastycinae (Anderson, 1999). The Sunda region is presented by 2 subfamilies: Draconinae, Leiolepidinae (Manthey \& Grossmann, 1997) and North Eurasian agamids are members of only the subfamily Agaminae (Ananjeva et al., 2006).

The subfamily Amphibolurinae is presented in Asia by the genus Physignathus which is the sister group to Australo-New Guinean agamids. At present the genus Physignathus includes 2 species: P. cocincinus and $P$. lessueurii. P. cocincinus inhabits the Southeast Asian region and part of China. Some authors provide evidence for a polyphyletic origin of this genus (Macey et al., 2000; Moody 1993; Schulte et al., 2003) which represents additional support for the ancient fragmentation of lizard taxa from both sides of Wallace's line (Schulte et al., 2003); another point of view suggests a much more recent divergence between SE Asian and Australian agamids (around 30 MYA) (Hugall \& Lee, 2004; Hugall et al., 2008). Agamids of this subfamily have femoral pores and lens-like skin receptors (Ananjeva, 2004).

The monotypic subfamily Leiolepidinae is known from Southeast Asia and part of China and Sulawesi in Sunda region. Study of mt-DNA (Macey et al., 2000) and morphological characters of the integument (Ananjeva et al., 2001) support the monophyly of this lineage, previously combined with Uromastyx into a 
subfamily (family) Uromastycinae (-dae) Theobald, 1868 (Moody, 1980). These lizards have femoral pores and lens-like receptors without hairs (Ananjeva, 2004; Ananjeva et al., 2001). Among 8 species there are bisexual ( $L$. belliana, L. guttata, L. reevesii, L. peguensis) and parthenogenetic: (L. triploida, $L$. guentherpetersi, L. boehmei, L.ngovantrii) (Darevsky \& Kupriyanova, 1993; Grismer \& Grismer, 2010) examples.

The lizards of the subfamily Uromastycinae with 18 species are distributed in western Asia and Africa. One of the species, belonging to genus Saara, is the widespread S. hardwickii Gray, 1827 which inhabits Pakistan, northwestern India (Rajasthan, Gujarat) and Afghanistan (area bordering Pakistan). Another species, S. asmussi (Strauch, 1863) also penetrates South Asia in Pakistan (Baluchistan).

The subfamily Draconinae contains the maximum diversity of genera and species in South and Southeast Asia (Ananjeva, 2004; Macey et al., 2000; Moody, 1980). This subfamily is the most diverse group with a high percent of endemic genera of arboreal and semiarboreal agamids (Moody, 1980). Among them there are monotypic genera or those represented by 1-3 species (Aphaniotis, Cophotis, Ptyctolaemus), as well as genera with high species diversity (Draco, Gonocephalus, Japalura). Draconine agamids exhibit very high degrees of diversification at the generic level (23 genera in South Asia and 24 genera in Southeast Asia). Phylogenetic studies conducted in recent decades have improved our knowledge about the composition and phylogeny of the subfamily. Some problems still exist relating to newly described or re-studied species in certain genera (Ananjeva \& Stuart, 2001; Macey et al., 2000; Maduwage et al., 2008; Manthey \& Grossmann, 1997; Schulte et al., 2002, 2004).

In the course of taxonomic revisions of the genera Acanthosaura (Ananjeva et al., 2008; Kalyabina-Hauf et al., 2004; Orlov et al., 2006; Wood et al., 2009, 2010), Bronchocela (Hallermann, 2004, 2005), Calotes (Bahir \& Maduwage, 2005; Hallermann, 2000; Ota \& Hikida, 1991, 1996; Vindum et al., 2003; Zug et al., 2006); Draco (Inger, 1983; McGuire \& Heand, 2001; Musters, 1983), Gonocephalus (Diong et al., 2000; Honda et al., 2002; Manthey \& Grossmann, 1997), Japalura (Ota, 1989a,b; 1991, 2000a,b; Ota \& Hikida, 1989; Ota et al., 1998), Pseudocalotes (Hallermann \& Böhme, 2000; Hallermann \& McGuire, 2001, Hallermann et al., 2010), Otocryptis (Bahir \& Silva, 2005), Cophotis (Samarawickrama et al., 2006) and Ptyctolaemus (Ananjeva \& Stuart, 2001; Manthey \& Nabhitabhata, 1991; Schulte et al., 2004) descriptions of a number of new species and even genera have been made. Moody (1980) revised the family Agamidae and divided the genus Agama into the following six genera: Agama, Stellio, Trapelus, Pseudotrapelus, Brachysaura and Xenagama.

The subfamily Agaminae comprises about 115 species living mainly in Africa and Palearctic Asia. In comparison with agamids of the subfamily Draconinae it is characterized by relatively low generic diversity (number of species in parentheses) - 9 genera in total: Acanthocercus Fitzinger, 1843 (about 10), Agama Daudin, 1802 (about 30), Brachysaura Blyth, 1856 (1), Bufoniceps Arnold, 1992 (1), Phrynocephalus Kaup, 1835 (40), Pseudotrapelus Fitzinger, 1843 (1), Laudakia Gray, 1845 (16), Trapelus Cuvier, 1817 (12), Xenagama Boulenger, 1895 (2). Problems of phylogenetic relations within Agaminae and position of monotypic genera are of increasing interest: DNA study revealed cryptic phylogenetic diversity (in particular non-monophyly of genus Laudakia) (Macey et al., 2000, 2006).

It has been recorded (Moody, 1980) that only 5 agamid genera (Draco, Japalura, Laudakia, Calotes and Uromastyx) cross the boundaries of the six regions of endemism (i.e. Subsaharan Africa, Eurasia, India, Orient and Sunda, Wallacia and Australia and Melanesia). This can be seen when we analyze agamid lists of China, South- Southeast Asia and other Asian regions. Comparison of the lists of specified Vietnamese agamids with those of several regions of South-East Asia (Myanmar, Thailand, Sunda region, China (Ananjeva \& Wang, 2008; Ananjeva et al., 2007; Manthey \& Grossmann, 1997; Zhao \& Adler, 1993; Zhao et al., 1999; Zug et al., 2003) shows species diversity increasing from 24 (Vietnam) to 29 in Myanmar and Thailand and 48 in China. The South Asia and Sunda regions have much higher species diversity (67 and 60 sp., respectively).

The methodology of phylogenetic systematics (Moody, 1980) as well as approaches and methods of molecular analysis (Ananjeva, 2004; Honda et al., 2000; Macey et al., 2000) have made a great contribution 
to the understanding of generic assignment of problematic species. However the problem of interpretation and phylogenetic evaluation of morphological characters remains and has a practical aspect with respect to the construction and use of identification keys.

The problem of the evaluation of the endemism of Asian agamids is of special importance in the context of conservation. Physiographically the South Asian region includes several parts: the northern islands of the Bay of Bengal Islands, the southern islands, different parts of India, plain and mountain regions of Pakistan and the continental island of Sri Lanka (Das, 1997). This region supports 23 endemic genera (many of them are monotypic) belonging to 3 subfamilies. It has the second agamid greatest diversity region after Southeast Asia (Moody, 1980). Within this region the Sri Lankan agamid fauna with its high level of endemism is of special interest: it supports 18 species (Das \& de Silva, 2005) representing 6 genera of one subfamily Draconinae; 15 of them are endemic to the island.

Among the 24 species in Vietnam, 12 species (50\%) are endemics. The distribution of 10 of the 12 endemics is delimited by the southern part of the Annamite Mountains. This is additional evidence for the designation of an Annam sub region with tropical mountain forests. Inger (1999) wrote that this region is one of the centres of active cryptic speciation in Asia for anurans. Only one endemic species, L. guentherpetersi, is described from Central Vietnam, one more from the Tonkin region (North Vietnam) - Japalura chapaensis. The other 10 species are known only from the Central Highland within Vietnam and adjacent regions of Laos and Cambodia (3 species Acanthosaura, 3 species Bronchocela, 1 species Draco, 1 species Leiolepis, 1 species Pseudocalotes and 1 species Pseudocophotis). In general the agamid fauna in Indochina is characterized by a high level of endemism and cryptic diversity. The data on cryptic diversity in genera such as Acanthosaura and Bronchocela confirm ideas about the diversification of the fauna of tropical forests (Moritz et al., 2000), which is illustrated by numerous examples from tropical faunas of Central Africa, Australia and South America.

The agamid fauna of China includes 48 species of 4 subfamilies and 13 genera. The level of endemism is relatively high (19 species, i.e. $44 \%)$. Endemic species are referred to 4 genera: among them majority of species of genus Japalura (10 among 14) and species of the Tibetan clade of the genus Phrynocephalus (7 of 11 species) (Ananjeva \& Wang, 2008).

These data and any attempts to summarize and analyze the modern data on biodiversity, level of endemism and allocations of the highest priority territories are of great value for conservation strategies.

\section{Literature Cited}

Ananjeva, N. B., 2004. Phylogeny and Biogeography of Agamid Lizards (Agamidae, Lacertilia, Reptilia): Review of Concepts and Results of Molecular and Morphological Studies, Uspechi Sovremennoi Biologii, 124 (1): 44-57.

Ananjeva, N. B. and B. Stuart, 2001. The agamid lizard Ptyctolaemus phuwuanensis Manthey and Nabhitabhata, 1991 from Thailand and Laos represents a new genus. Russian Journal of Herpetology, 8 (3): 165-170.

Ananjeva, N. B. and Wang Yu., 2008. Analysis of biodiversity of the fauna of agamid lizards (Agamidae, Sauris, Reptilia) of China. Current Research in Herpetology, 8 (1): 10-29.

Ananjeva, N. B., T. N. Dujsebayeva and U. Joger, 2001. Morphological study of squamate integument: more evidence for the metataxon status of Leiolepidinae . Journal of Herpetology, 35 (3): 69-74.

Ananjeva, N. B., N. L. Orlov and N. Q. Truong, 2007. Agamid lizards (Agamidae, Acrodonta, Sauria, Reptlia) of Vietnam. Mitteilungen aus dem Museum für Naturkunde in Berlin, Zoologische Reihe, Supplement 83: 13-21. 


\section{EDITORIAL}

Ananjeva, N. B., N. L. Orlov and S. A. Kalyabina-Hauf, 2008. Species of Acanthosaura Gray, 1831 (Agamidae: Sauria, Reptilia) of Vietnam: results of molecular and morphological study. Biology Bulletin, 35 (2): 178-186.

Ananjeva, N. B., N. L. Orlov, R. G. Khalikov, I. S. Darevsky, S. A. Ryabov and A. V. Barabanov, 2006. Atlas of the reptiles of North Eurasia (taxonomic diversity, distribution, conservation status). Pensoft: 246.

Anderson, S. C., 1999. The lizards of Iran. Contribution to Herpetology. 15, Society for the Study of Amphibians \& Reptiles: 442.

Bahir, M.M. and K.P. Maduwage, 2005. Calotes desilvai, a new species of agamid lizard from Morningside Forest, Sri Lanka. In: Yeo, D. C. J., P. K. L. Ng and R. Pethiyagoda (Eds.). Contributions to biodiversity exploration and research in Sri Lanka. The Raffles Bulletin of Zoology, Supplement No. 12: 381-392.

Bahir, M.M. and A. Silva, 2005. Otocryptis nigristigma, a new species of agamid lizard from Sri Lanka. In: Yeo, D. C. J., P. K. L. Ng and R. Pethiyagoda (Eds.). Contributions to biodiversity exploration and research in Sri Lanka. The Raffles Bulletin of Zoology, Supplement No. 12: 393-406.

Darevsky, I. S. and L. A. Kupriyanova, 1993. The two all-female lizard species of the genus Leiolepis Cuvier, 1829 from Thailand and Vietnam (Squamata: Sauria: Uromastycidae). Herpetozoa, 6 (1\&2): 3-20.

Das, I., 1996. Biogeography of the reptiles of South Asia. Malabar, Krieger Publishing Company: 87.

Das, I. and A. de Silva, 2005. Photographic guide to the Snakes and other reptiles of Sri Lanka. New Holland Publishers, UK: 144.

Diong, C.-H., M. -H. Low, E-Co. Tan, H.-S. Yong, T. Hikida and H. Ota, 2000. On the monophyly of the agamid genus Gonocephalus Kaup, 1925 (Reptilia: Squamata): A chromosomal perspective. Current Herpetology, 19 (2): 71-79.

Grismer, J. L., L. L. Grismer, 2010. Who's your mommy? Identifying maternal ancestors of asexual species of Leiolepis Cuvier, 1829 and the description of a new endemic species of asexual Leiolepis Cuvier, 1829 from Southern Vietnam. Zootaxa, 2433: 47-61

Hallermann, J., 2000. A new species of Calotes from the Moluccas (Indonesia) with notes on the biogeography of the genus (Sauria: Agamidae). Bonner zoologische Beiträge, 49 (1-4): 155-163.

Hallermann, J., 2004. A new species of the genus Bronchocela from the tropical rain forest of southern Vietnam. Russian Journal of Herpetology, 11 (1): 30-34.

Hallermann, J., 2005. A taxonomic review of the genus Bronchocela (Squamata: Agamidae) with description of a new species from Vietnam. Russian Journal of Herpetology, 12 (3): 167-182.

Hallermann, J. and W. Böhme, 2000. A review of the genus Pseudocalotes (Squamata:Agamidae) with description of a new species from West Malaysia. Amphibia-Reptilia, 21: 193-210.

Hallermann, J. and J. A. McGuire, 2001. A new species of Pseudocalotes (Squamata: Agamidae) from Bukit Larut, West Malaysia. Herpetologica, 57 (3): 255-265.

Hallermann, J., N. Q. Truong, N. Orlov and N. Ananjeva, 2010. A new species of the genus Pseudocalotes (Squamata: Agamidae) from Vietnam. Russian Journal of Herpetology, 17 (1): 31-40.

Honda, M., H. Ota, M. Kobayashi, J. Nabhitanhata, Hoi-Sen Yong, S. Sengoku and T. Hikida, 2000. Phylogenetic relationships of the family Agamidae (Reptilia: Iguania) inferred from mitochondrial DNA sequences. Zoological Science, 17 (5): 527-537. 
Honda, M., H. Ota, M. S. Sengoku, Hoi-Sen Yong and T. Hikida, 2002. Molecular evaluation of phylogenetic significance in the highly divergent karyotypes of the genus Gonocephalus (Reptilia: Agamidae) from tropical Asia. Zoological Science, 19 (1): 129-133.

Hugall, A. F and M. S. Lee, 2004. Molecular claims age for Austrakuab agamid lizards are unstable. Molecular Biology and Evolution, 21(11): 2102-2110.

Hugall, A. F., R. Foster, M. Hutchinson and M. S. Lee, 2008. Phylogeny of Australasian agamid lizards based on nuclear and mitochondrial genes: implications for morphological evolution and biogeography. Biological Journal of the Linnean Society, 93: 343-358.

Inger, R. F., 1983. Morphological and ecological variation in the flying lizards (genus Draco). Fieldiana: Zoology. New Series, 18: 1-37.

Inger, R. F., 1999. Distribution of amphibians in Southern Asia and adjacent islands, in Patterns of Distribution of Amphibians: A Global Perspective. In: Duellman, W. E. (Ed.). Baltimore, MD: J. Hopkins Univ. Press: 445-482

Kalyabina-Hauf, S., N. Ananjeva, U. Joger, P. Lenk, R. W. Murphy, B. L. Stuart, N. L. Orlov, C. T. Ho and M. Wink, 2004. Molecular phylogeny of the genus Acanthosaura (Agamidae). Current Herpetology, 23 (1): 7-16.

Macey, J. R., J. A. Schulte, A. Larson, N. Ananjeva, Y. Wang and R. Pethiyagoda, 2000. Evaluating TransTethys Migration: An Example Using Acrodont Lizard Phylogenetics. Systematic Biology, 49 (2): 233-256.

Macey, J. R., J. A. Schulte, J. J. Fong, I. Das and T. Papenfuss, 2006. The complete mitochondrial genome of an agamid lizards from the Afro-Asian subfamily Agaminae and the phylogenetic position of Bufoniceps and Xenagama. Molecular Phylogenetics and Evolution, 39: 881-886.

Maduwage, K., M. Meegaskumbura, A. Silva and R. Pethiyagoda, 2008. Phylogenetic implications of hemipenial morphology of Sri Lankan agamid lizards. Current Science, 95 (7): 838-640.

Manthey, U. and J. Nabhitabhata, 1991. An agamid lizard, Ptyctolaemus phuwuanensis Manthey \& Nabhitabhata 1991 (Sauria, Agamidae) from Northeast-Thailand. Sauria (E), 1 (2): 3-6.

Manthey, U. and W. Grossmann, 1997. Amphibien and Reptilien Südostasien. Münster. Natur and Tier Verlag: 512.

McGuire, J. A. and K. B. Heand, 2001. Phylogenetic systematics of Southeast Asian flying lizards (Iguania: Agamidae: Draco) as inferred from mitochondrial DNA sequence data. Biological Journal of the Linnean Society, 72: 203-229.

Moody, S., 1980. Phylogenetic and historical biogeographic relationships of the genera in the family Agamidae (Reptilia, Lacertilia): Unpubl Ph. D. Diss. Univ. Michigan. Ann Arbor: 373.

Moody, S., 1993. Wallace's line and the basal clades within the agamidae (Iguania, Lacertilia) or do morphologies and molecules clash. Abstracts of the Second World Congress of Herpetology. Adelaide, Australia: 173.

Moritz, C., J. L. Patton, C. J. Schneider and T. B. Smith, 2000. Diversification of rainforest faunas: an integrated molecular approach. Annual Revue Ecology Systematics, 31: 633-563.

Musters, C. J. M., 1983. Taxonomy of the genus Draco L. (Agamidae, Lacertilia, Reptilia). Zoologische Verhandelingen, 199: 1-120. 


\section{EDITORIAL}

Orlov, N. L., N. Q. Truong and N. V. Sang, 2006. A new Acanthosaura allied to A. Guenther, 1861 (Agamidae, Sauria) from Central Vietnam and Southern Laos. Russian Journal of Herpetology, 13 (1): 6176.

Ota, H., 1989a. A new species of Japalura (Agamidae: Lacertidae: Reptlia) from Taiwan. Copeia, 45 (3): 569-576.

Ota, H., 1989b. The status of agamid lizard, Japalura swinthonis chapaensis Bourret, 1938, from Vietnam. Journal of Herpetology, 23 (4): 447-450.

Ota, H., 1991. Taxonomic redefinition of Japalura swinhonis Günther (Agamidae: Squamata), with a description of a new subspecies of J. polygonata from Taiwan. Herpetologica, 47 (3): 280-294.

Ota, H., 2000a. Japalura szechwanensis, a junior synonym of H. fasciata. Journal of Herpetology, 34 (4): 611-614.

Ota H., 2000b. On the validity of Japalura yunnanensis popei Wettstein, 1938 (Squamata: Agamidae). Amphibia-Reptilia, 21 (4): 397-403.

Ota, H. and T. Hikida, 1991. Taxonomic review of the lizards of the genus Calotes Cuvier 1817 (Agamidae: Squamata) from Sabah, Malaysia. Tropical Zoology, 4: 179-192.

Ota, H. and T. Hikida, 1996. The second specimen of Calotes kinabaluensis Ota, 1989. A new species of Japalura (Agamidae: Lacertidae: Reptlia) from Taiwan. Copeia, 45 (3): 569-576.

Ota, H. and T. Hikida, 1989a. The status of agamid lizard, Japalura swinthonis chapaensis Bourret, 1938, from Vietnam. Journal of Herpetology, 23 (4): 447-450.

Ota, H., M. Matsui, T. Hikida and A. Mori, 1992. Extreme karyotypic divergence between species of the genus Gonocephalus (Reptilia: Squamata: Agamidae) from Borneo and Australia. Herpetologica, 48 (1): 120-124.

Ota, H., S.-L. Chen and G. Shang, 1998. Japalura luei: a new agamid lizard from Taiwan (Reptilia: Squamata). Copeia, 54 (3): 649-656.

Samarawickrama, V. A. M. P. K., K. B. Ranawana, D. R. N. S. Rajapaksha, N. B. Ananjeva, N. L. Orlov, J. M. A. S. Ranasinghe and V. A. P. Samarawickrama. 2006. A new species of the genus Cophotis (Squamata: Agamidae) from Sri Lanka. Russian Journal of Herpetology, 13 (3): 207-214.

Sang, N. V., H. T. Cuc and N. Q. Truong, 2009. Herpetofauna of Vietnam, Edition Chimaira, Frankfurt am Main: 768.

Schulte II, J. A., A. Larson, J. R. Macey and R. Pethiyagoda. 2002. Rostral horn evolution among agamid lizards of the genus Ceratophora endemic to Sri Lanka. Molecular Phylogenetic and Evolution, 22: 111117.

Schulte II, J.A., J. Melville and A. Larson, 2003. Molecular phylogenetic evidence for ancient divergence of lizards taxa on either side of Wallace's line. Proceedings of the Royal Society of London, Series B (Biological Sciences), 270: 597-603.

Schulte II, J. A., J. Vindum, H. Win, T. Thin, K. S. Lwin and A. K. Shein, 2004. Phylogenetic relationships of the genus Ptyctolaemus (Squamata: Agamidae), with a description of a new species from the Chin Hills of western Myanmar. Proceedings of the California Academy of Sciences. Ser. 4, 55 (12): 227-247. 


\section{EDITORIAL}

Smith, M. A., 1935. Reptilia and Amphibia. II. Sauria. The Fauna of British India including Ceylon and Burma. London: 440.

Taylor, E. N., 1963. The lizards of Thailand. Kansas University Scientific Bulletin, 46 (5): 687-1077.

Vindum, J. V., H. Win, T. Thin, K. S. Lwin, A. Khein and K. Tun, 2003. A new Calotes (Squamata: Agamidae) from the Indo-Burman Range of western Myanmar (Burma). Proceedings of the California Academy of Sciences. Series 4, 54 (1): 1-16.

Wood, P. L. J., J. L. Grismer, L. L. Grismer, A. Norhayati, C. K. Onn, A. M. Bauer, 2009. Two new montane species of Acanthosaura Gray, 1831 (Squamata: Agamidae) from Peninsular Malaysia. Zootaxa, 2012: $28-46$

Wood, P. L., L. L. Grismer, J. L. Grismer, T. Neang, T. Chav and J. Holden, 2010. A new cryptic species of Acanthosaura Gray, 1831 (Squamata: Agamidae) from Thailand and Cambodia. Zootaxa, 2488: 22-38.

Zhao, E.-M., K. Adler, 1993. Contribution to Herpetology 10, Society for the Study of Amphibians \& Reptiles: 521.

Zhao, E.-M., K. Zhao and Z. Kaiya, 1999. Fauna Sinica. Reptilia. 2. Squamata. Lacertilia. Beijing: 394.

Zug, G. R., A. E. Leviton, J. V. Vindum, G. O. U. Wogan and M. S. Koo, 2003. Lizards/Herpetofauna of Myanmar/California Academy of Sciences (www.calacademy.org/research/herpetology/myanmar/).

Zug, G. R., H. H. K. Brown, J. A. Schulte II and J. V. Vindum, 2006. Systematics of the Garden Lizards, Calotes versicolor Group (Reptilia, Squamata, Agamidae), in Myanmar: Central Dry Zone Populations. Proceedings of the California Academy of Sciences. Series 5, 57: 35-68.

\section{Acknowledgements}

I would like to thank Alain Dubois and Annemarie Ohler (MNHN), Wolfgang Böhme (ZFMB), Rainer Günther (ZMB), Jakob Hallermann (ZMH), Robert Inger, Harold Voris, and Alan Resetar (FMNH), V.F. Orlova, A. Dunaev (ZMMGU), Colin McCarthy (BMNH), Robert Murphy (ROM) and George Zug (USNM) providing us museum specimens for this study. This work was supported by MNHN professorship in 2004-2007, grants RFFI 09-04-00132a, 11-04-93981-INISa and program for support of scientific schools NSH 4212.2006.4.

Natalia B. Ananjeva

Sectional Editor: Taprobanica, the journal of Asian Biodiversity

January $28^{\text {th }}, 2011$

Department of Herpetology

Zoological Institute, Russian Academy of Sciences

Universitetskaya emb. 1

199034 St. Petersburg

RUSSIA 